\title{
Sound Pollution and Radiation Impact Survey of OML II Green Energy 'Obolo' Nigeria
}

\author{
F. U. Nte ${ }^{1}$ G. F. Aman ${ }^{2}$ \\ Department of Physics, Faculty of Science \\ University of Port Harcourt \\ Port Harcourt, Rivers State \\ Nigeria
}

\begin{abstract}
Sound pollution has been a major challenge in both the developed and the developing nations and demand serious attention to check the health hazards, just as is the case of radiation studies. The effort is a drift from the urban noise to the rural oil and gas producing communities of Nigeria, taking Oil Mining Lease II as a case study. The communities cover Ebukuna, AmaUbulom, Amajob, Ama-Ngerenkpon, Agbalama, Otako, Okoloile, Ama-Friday, Otu-Ogon and Ngo town, in the other of 1 to 10 respectively. The communities have a noise range of $44.49 \mathrm{dBA}$ to $63.60 \mathrm{dBA}$, with Ebukuna ranking highest and Otako lowest. This is indicative that the Oil and Gas industrial activities do not have adverse noise effect from delivery pipes. The participatory investigation shows severity from oil spills, which has left the creeks barren and caused migration of the citizenry across the shores of Nigeria and West Africa for green fishing. A complementary research results of the radionuclide contents of $40 \mathrm{k}(\mathrm{Bq} / \mathrm{l})$, ${ }^{235} \mathrm{Ra}(\mathrm{Bq} / \mathrm{L}) \mathrm{m}$ show the values twice above the recommended standard by WHO in table 2 , which is indicative of the Oil spill impact in the region and transport from Ogoni spill down to Andoni (Obolo) as the ultimate sink. The UNSCEAR of the bottom sediment is even much higher
\end{abstract}

Keywords—Radiation, Sound Pollution

\section{INTRODUCTION}

Andoni (Obolo) is one of the 774 local government areas of Nigeria and among the 23 local government areas of Rivers State. It is located on $7^{0} 18^{1} \mathrm{E}$ and $7^{0} 33^{1} \mathrm{E}$ of Greenwich meridian but transverse laterally by latitude $4^{0} 31^{1} \mathrm{~N}$. it is bounded by the Ogoni's in the North, Bonny to the West, Imo River/Opobo /Ikot Abasi to the East and the Atlantic Ocean to the South. It has seven multinational firms on its land and offshore, namely;

1. AMNI, International Petroleum Development Company (Ngo field)

2. $\quad$ Chevron Tubu field Development OML 52

3. $\quad$ Elf Petroleum Nigeria Limited OML (100)

4. NNPC Joint Venture, Offshore Operations OML 99, OML 101, OML 102 with Production capacity of 500 million barrels of oil

5. Mobil Oil Fields Eastern Obolo and Ibeno Ethnic brothers

6. Shell Petroleum Development Company of Nigeria Otakukpo field

7. The Green energy International Limited and Lek Oil Collaboration on OML II and OML 52.

A lot of competitive study has been done on sound pollution impact.

These include [1] - [23].

The study show both the impact of noise and radiological hazard index for most communities as above the WHO standards and need a good environmental health educators to enlighten the people and government

\section{METHOD}

The methods involves the use of a CEL 231 and CEL 254 Digilert 100 and radalert 200, geographical positioning system (GSP) and a participatory tool box for forensic investigation of Oil and Gas exploitation impact.

The result and analysis are as shown in table 1: Baseline flow station noise level of facilities while figures 1 - 4 tells us specific noise details at the surveyed point

At the close; table 2 gives us summary of the radiation index in water while fig 5 show us the contour of the spread, fig 6 at the summary is indicative of the average noise level for the 10 sampled communities, which is minimal. 
III. RESULTS

TABLE1. Sound pollution survey of flow station facilities

\begin{tabular}{|c|c|c|c|c|}
\hline $\mathrm{S} / \mathrm{N}$ & FACILITIES & OPERATION & $\begin{array}{l}\text { NOISE } \\
(\mathrm{Dba})\end{array}$ & $\begin{array}{l}\text { Range } \\
(\mathrm{m})\end{array}$ \\
\hline 1 & Wind level/ Helipad & Transport & $60-80$ & 500 \\
\hline 2 & Communication platform & $\begin{array}{l}\text { Radio } \\
\text { transmission }\end{array}$ & $50-70$ & 500 \\
\hline 3 & Oil pumps/engine/metering & Compression & $80-100$ & 1000 \\
\hline 4 & Perimeter drain and wall & Drainage & Negligible & Sink \\
\hline 5 & Pipelines and manifold & Oil delivery & High pressure & Linear \\
\hline 6 & Platform and gantry & 'base/floor & Negligible & Static \\
\hline 7 & Reservoir ( fuel tank)/ gate vales & Storage & Negligible & Static \\
\hline 8 & Rig stand/swids and operations & Base & $\begin{array}{l}\text { 65-135dBA } \\
\text { impulsive }\end{array}$ & 500 \\
\hline 9 & Roads and drill slot marine & Assess & Negligible & Static \\
\hline 10 & Saver pit/flow channel & $\begin{array}{l}\text { Drainage } \\
\text { recycling }\end{array}$ & Negligible & Linear - \\
\hline 11 & Swamp dozer, pipeline & $\begin{array}{l}\text { Excavation } \\
\text { laying of pipe }\end{array}$ & $80-90$ & 500 \\
\hline 12 & Test separators/scrubbers & Processing & $70-90$ & 500 \\
\hline 13 & Seismic blast " exploration & Dynamites & $100-140$ & 1200 \\
\hline 14 & Simo pumps and bole hole & Pumping & $60-80$ & 400 \\
\hline 15 & Surge vessels & Vertical tank & $50-70$ & 200 \\
\hline 16 & Swamps and wild life & Ecological & Negligible & Random \\
\hline 17 & Sewage/septic tanks & Discharge & Negligible & Static \\
\hline 18 & Gas flare stark & $\begin{array}{l}\text { Heat radiation } \\
\text { and sound }\end{array}$ & N60-88 & Zoom \\
\hline 19 & Well head "Christmas tree" & Well & Negligible & Static \\
\hline 20 & Work site/ generators & Camp & $60-80$ & 500 \\
\hline
\end{tabular}

Average minimum 55dBA \pm 2 , average minimum $87 \mathrm{dBA} \pm 5$ SPDC facility

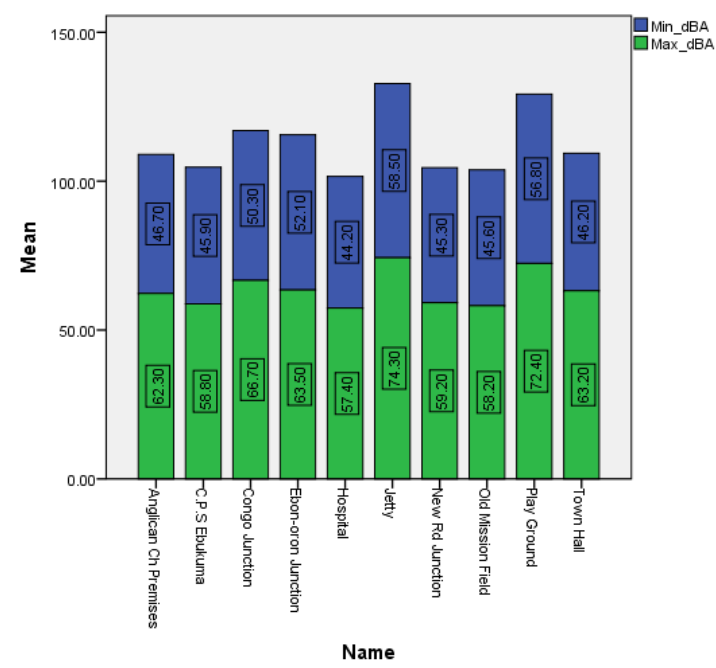

Figure1. Noise level of Ebukuma Community in Andoni L.G.A

From the above chart, we see that:

- The residents of Jetty village are exposed to the most noise (74.30dBA) in this community.

- Those living around Hospital are least affected (44.20dBA) by the noise in the community. 


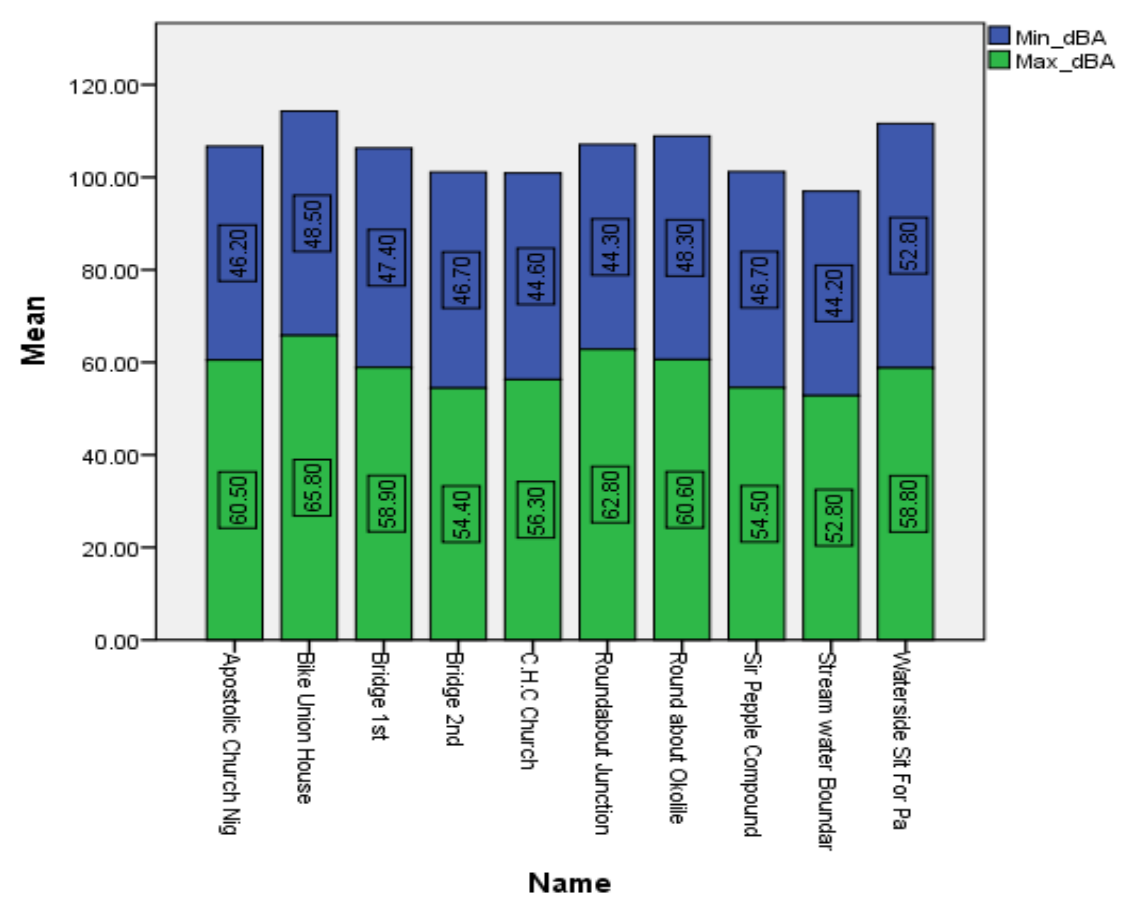

Figure 2. Noise Level of Ama-Ubulom Community in Andoni L.G.A

From the above chart, we see that:

-The residents of Bike Union House are exposed to the most noise $(65.80 \mathrm{dBA})$ in this community.

-Those living around Stream Water Boundary are least affected (44.20 dBA) by the noise in the community.

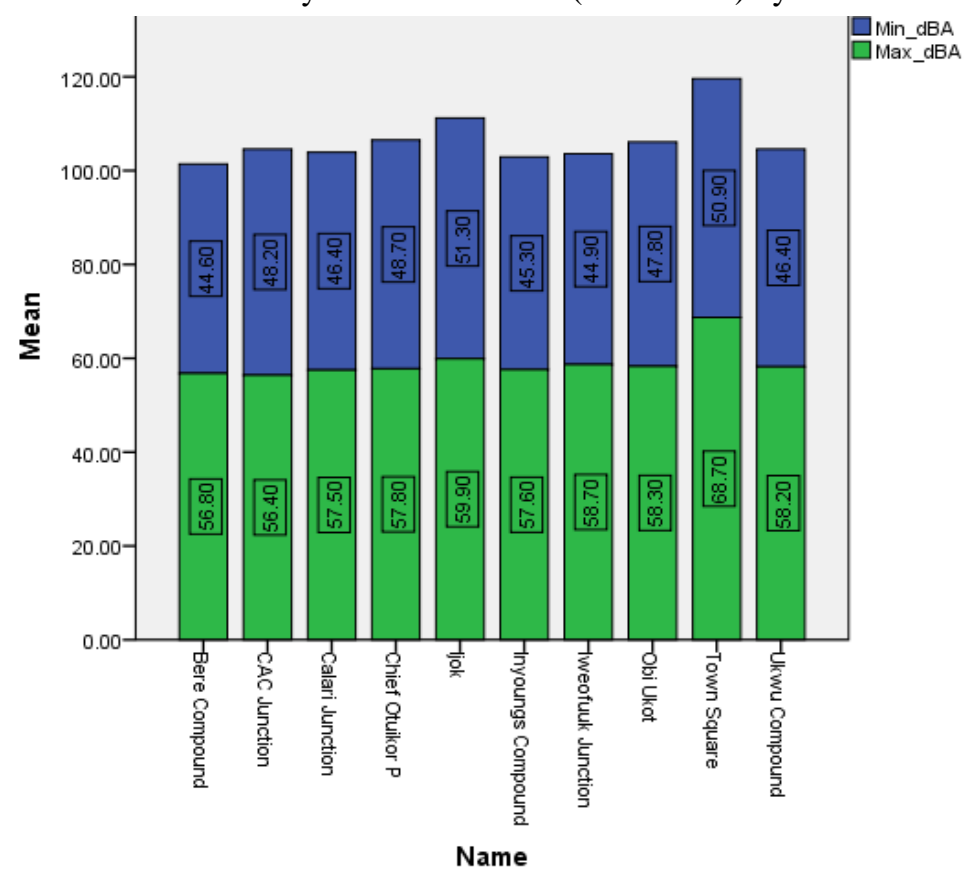

Figure3. Noise level of Agbalama Community in Andoni L.G.A

From the above chart, we see that:

-The villagers staying around Town Square are exposed to the most noise $(68.70 \mathrm{dBA})$ in this community.

-Those living around Bere Compound are least affected (44.60 dBA) by the noise in the community. 


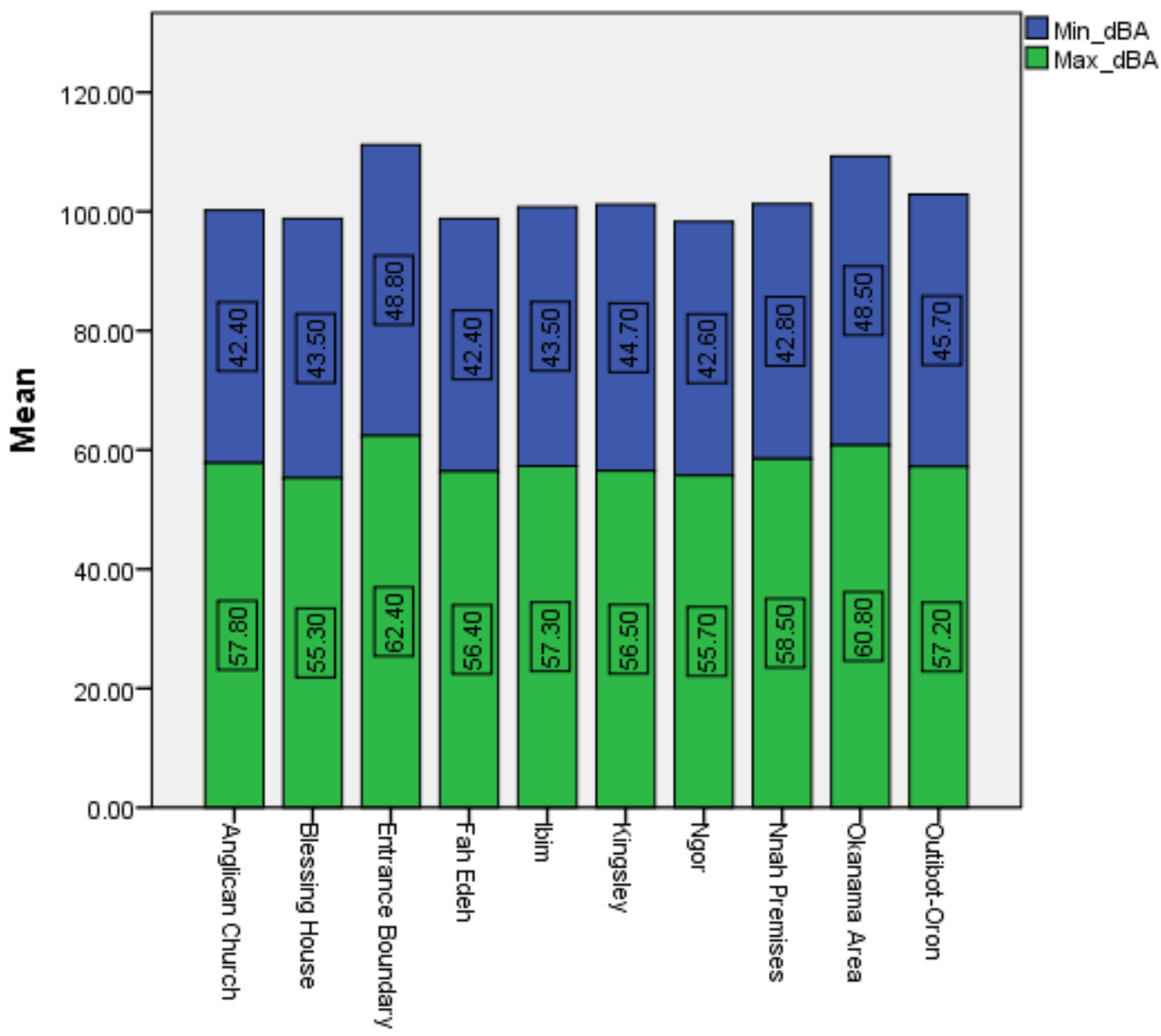

Name

Figure4. Noise level of Otako Community in Andoni L.G.A

From the above chart, we see that:

-The villagers staying around the Entrance Boundary are exposed to the most noise $(62.40 \mathrm{dBA})$ in this community.

-Those living around the Anglican Church and Fah Edeh are least affected (42.40 dBA) by the noise in the community.

Table2. Radiation hazard indices in sea water

\begin{tabular}{|c|c|c|c|c|c|c|c|c|}
\hline $\mathbf{S} / \mathbf{N}$ & Location & $\begin{array}{l}\text { Raeq } \\
(\mathrm{Bq} / \mathrm{l})\end{array}$ & $\begin{array}{l}\text { Hex } \\
\left(\mathrm{mSvy}^{-1}\right)\end{array}$ & $\begin{array}{l}\text { Hin } \\
\left(\mathrm{mSvy}^{-1}\right)\end{array}$ & $\begin{array}{l}\text { D } \\
\left(\mathrm{nGyh}^{-1}\right)\end{array}$ & $\begin{array}{l}\text { AEDE } \\
\left(\mathrm{mSvy}^{-1}\right)\end{array}$ & $\begin{array}{l}\text { Gonadal } \\
\left(\mathrm{mSvy}^{-1}\right)\end{array}$ & $\begin{array}{l}\text { ELCR } \\
\times 10^{-3}\end{array}$ \\
\hline 1 & NGS 1 & 153.33 & 0.414 & 0.497 & 67.71 & 0.08 & 456.27 & 0.29 \\
\hline 2 & NGS 2 & 201.35 & 0.544 & 0.617 & 88.70 & 0.11 & 598.58 & 0.38 \\
\hline 3 & NGS 3 & 103.99 & 0.281 & 0.337 & 46.68 & 0.06 & 317.59 & 0.20 \\
\hline 4 & NGS 4 & 166.85 & 0.451 & 0.492 & 73.61 & 0.09 & 498.15 & 0.32 \\
\hline 5 & NGS 5 & 166.81 & 0.450 & 0.498 & 73.52 & 0.09 & 496.89 & 0.32 \\
\hline 6 & ECS 6 & 117.20 & 0.317 & 0.394 & 52.02 & 0.06 & 350.93 & 0.22 \\
\hline 7 & AFS 7 & 150.14 & 0.406 & 0.494 & 66.40 & 0.08 & 447.45 & 0.29 \\
\hline 8 & AFS 8 & 149.35 & 0.403 & 0.468 & 65.71 & 0.08 & 442.62 & 0.28 \\
\hline 9 & OTS 9 & 118.96 & 0.321 & 0.364 & 52.66 & 0.07 & 356.40 & 0.23 \\
\hline 10 & AGS 10 & 99.12 & 0.268 & 0.352 & 44.06 & 0.05 & 296.55 & 0.19 \\
\hline \multicolumn{2}{|c|}{ MEAN VALUE } & 142.71 & 0.385 & 0.451 & 63.11 & 0.08 & 426.14 & 0.27 \\
\hline \multicolumn{2}{|c|}{ UNSCEAR 2000} & 370 & 1 & 1 & 57 & 1 & 300 & 0.29 \\
\hline
\end{tabular}

From table 2 which shows the average Radiation Hazard Indices in Sea Water it is established that the index is above world health organization by twice the value and needs more caution as to the source and the impact on the fishing community which is a major discovery. 


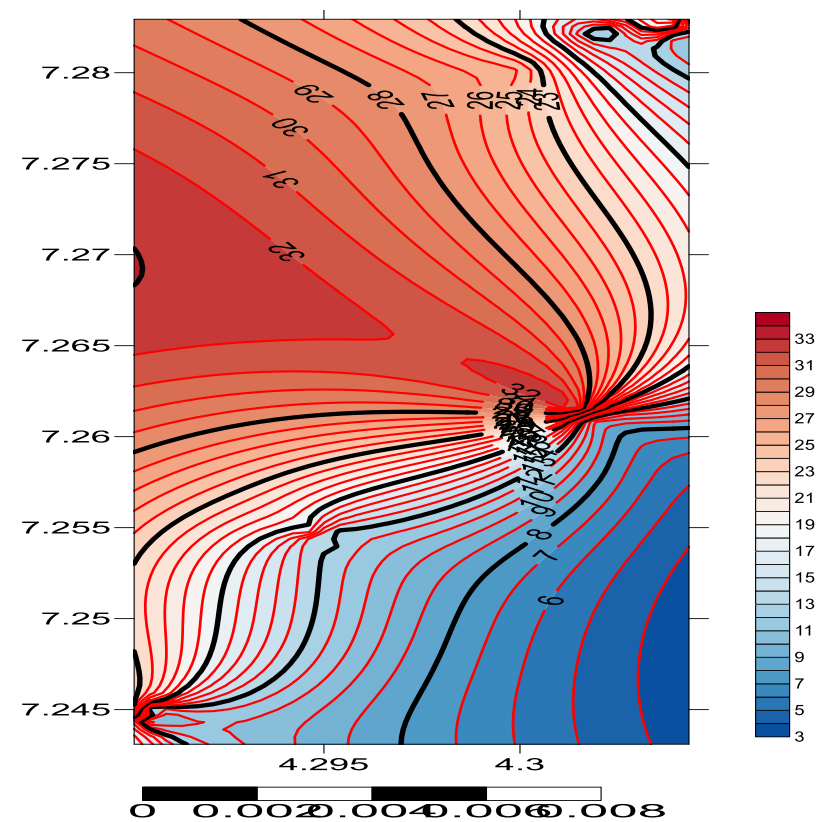

Figure5. Contour mapping of Ama-Friday, Otu-Ogoon, Ngo and Ebukuma Communities

The figure 5 shows the distribution of the Radiation Hazard Indices in Sea Water among the riverine community of the surveyed field.

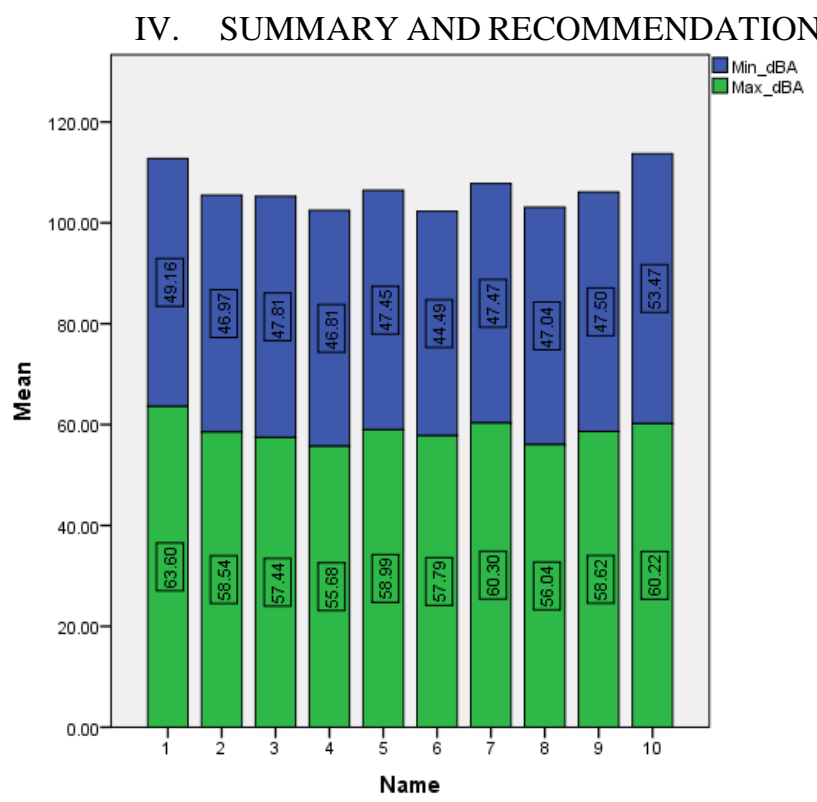

Figure6. Average noise level for all Communities showing minimal impact

Sound pollution and radiation impact survey of OML II was carried out. The findings shown in figure 1-4 is indicative that industrial noise impact from network of oil and gas pipeline is negligible but could escalate for flow stations on full production process. Reference table 1.

The radio nucleic activity concentration in the water of the study area is very high, reference Table 2 . This is traceable to the heavy drill work in the area, oil spillages and drift oil and gas pollutant from the 'Ogoni' leakages and remediation work in Ogoni which is North of Andoni, the study area. The recommendation is for an integrated environmental evaluation, remediation and rehabilitation of the people on aqua cultural alternatives to boost fish production. 


\section{REFERENCES}

[1] Avwiri, G.O, Ononugbo C.P, and Nwokeoji L.E, Radiation hazard indices and excess lifetime cancer risk in soil, sediment and water around MiniOkoro/Oginigba Creek, Port Harcourt, Rivers State, Nigeria, 2014, Compr. J. of Environ Earth Sc, 3(1), pp.38-50.

[2] Aydan, A., Seref T., and Hasan G., The natural and artificial radionuclides in drinking water samples and consequent population doses, Direct science journals, 8(4), 2015, pp.578-582.

[3] Ballinger, P.W., National radiation, radiographic position and procedures, Mosby year book 1, 1991, pp.21-32.

[4] Chad-Umoren, Y.E., Ionizing radiation profile of the hydrocarbon belt of Nigeria in Mitsuru Nenoi (Editor): Current topics in ionizing radiation research, Intech Publications, JanezaTrdine 9, 51000 Rijeka, Croatia, 2012, 978-953.

[5] Eludoyin, O. S, Oduore T and Obafemi A. A (2012). Spatio - temporal analysis of shorelin marine environment, pp.579-582. Essiett, A.A., Essien, I.E. and Bede, M.C., Measurement of surface dose rate of nuclear radiation in coastal areas of Akwa Ibom State, Nigeria. International Journal of Physics, 3(5), 2015, pp.224-229.

[6] "Radiation" Retrieved from https://en.wikipedia.org/wiki/Radiation.

[7] Jibiri, N.N., and Okeyode, I.C., Evaluation of radiological hazards in the sediments of Ogun river, South-Western, Nigeria. Radiation Physics and Chemistry, 81, 2012, pp.1829-1835.

[8] Laogun, A.N, Ajayi, O., and Agaja, S.A, Variation in well-head gamma radiation levels at the Nigerian Petroleum Development Company oil field, 2006.

[9] Ologbo, Edo State, Nigeria. Nigeria Journals of Physics, 18(1), pp.735 - 140

[10] Masok F.B, Ike-Ogbonna, M.I, Dawam, R..R, Jwanbot, D.I and Yenle, N.M., Cancer risk due to radionuclides concentration in tin ores and sediments at Barkin-Ladi, Plateau State, North Central, Nigeria. International Journal of Environmental Monitoring and Analysis, 2015, pp.2328- 7659.

[11] Mohammad, A.K, Omar, E., KLhaled, Z. and Ibraham, R., Assessment of indoor and outdoor radon levels in South Lebanon. International Journal of Disaster Risk Science, 5(3), 2014, pp.214 - 226.

[12] Muhammad, R., Saeed U.R.., Muhammad, B., Wajid, A., Iftikhar, A., Khursheed, A., Khalli, A., and Matiullah., Evaluation of excess life time cancer risk rom gamma dose rates in Jhelum valley. Journal of Radiation Research and Applied Science, 7, 2014, pp.29-35.

[13] Nte, F.U., and Esi E.O., Evaluation of Radiological Hazard Indices and Excess like Cancer Risk in Ishiagu Quarry Site, Ebonyi State. Nes, 2017 Conference paper, 2017.

[14] Ononugbo, C.P., Avwiri, G.O, and Tutumeni, G., Estimation of indoor and outdoor effective doses from gamma dose rates of residential buildings in Emelogu Village in Rivers State, Nigeria. International Research Journal of Pure and Applied Physics (IRJPAP), 3(2), 2015, pp.18-27.

[15] Ononugbo. C.P. and Anyalebechi C.D., Natural radioactivity levels and radiological risk assessment of surface water from coastal communities of Ndokwa East, Delta State, Nigeria. Physical Science International Journal, 14(1), 2016, pp.2348-0130.

[16] Ononugbo, C.P., Avwiri, G.O. and Ogan, C.A., Natural radioactivity measurement and evaluation of radiological hazards in sediment of Imo River, In Rivers State, Nigeria by gamma ray spectrometry. Journal of Applied Physics (IOSR-JAP) 8(3), 2016, pp.75-83.

[17] Ricardo, A.M., Serafim, L., Bianca, A., Correal, M., Yone, M.Y., Primil, M.C, and Luiz P.G, Investigation of the uranium content in sediment and soil samples from the santos and sao vicente estuary region, sp. International Nuclear Atlantic Conference - IN AC 2009 Associagdo Brasileira De Energia Nuclear - Aben Ishn:8(3), 2009, pp.978-985.

[18] Sivakumara, S., Chandrasekaranb, A., Ravisankare, R., Ravikumare, S., Prince, M.J., Prakash, J., Vijayagopale, P., Vijayalashmie, I. and Jose, M.T., Measurement of natural radioactivity and evaluation of radiation hazards in coastal sediments of east coast of Tamilnadu using statistical approach Journal of Taibah University for Science, 8, 2014, pp.375- 384.

[19] Taskin, H., Karavus, M., Topuzoglu, A., Hidiroglu, S., and Karahan, G., Radionuclide concentration in soil and lifetime cancer risk due to the gamma radioactivity in Kirklarei, Turkey, Journal of Environmental Radioactivity, 100, 2009, pp.49-53.

[20] UNSCEAR, United Nations Scientific Committee of the Effects of Atomic Radiation, Report to the General Assembly with Scientific Annexes. United Nation New York 1993. Pp.922.

[21] UNSCEAR, United Nations Scientific Committee of the Effects of Atomic Radiation, Annex B, Sources and effects of ionizing radiation, 1, 2000, pp. $121-476$.

[22] United Nations Scientific Committee on Effect of Atomic Radiation (UNSCEAR), (2000). Exposure from natural radiation source; Report to the general assembly Annex B.

[23] Yehuwdah, E.C. and Chioma P. E, Trends in effective nuclear waste management procedures: Options for Nigeria's emerging nuclear power industry, Journal of Natural Sciences Research 4(23), 2014, pp.2224-3186. 